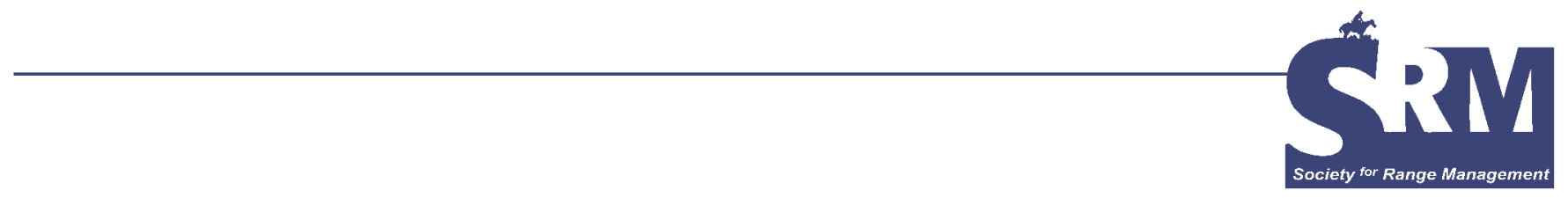

\title{
Cattle Raising in Central, Semiarid Rangelands of Argentina
}

\section{By Hugo D. Giorgetti, Carlos A. Busso, Oscar A. Montenegro, Gustavo D. Rodríguez, and Nora M. Kugler}

\section{Introduction}

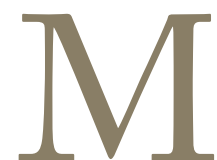

ost rangelands are managed inappropriately in Argentina. This article provides some simple guidelines that can ensure a better grazing of rangeland vegetation and simultaneously increase beef production. Our main objective was to prove that a few simple management guidelines and a short-duration, high-intensity grazing system would increase beef production per acre, while at the same time maintaining the forage resource in the community.

Studies were conducted in the phytogeographical province of the Monte $^{1}$ (Fig. 1, 40 $39^{\prime} \mathrm{S}, 62^{\circ} 54^{\prime} \mathrm{W}$ ) in central Argentina. Average annual temperature is $54^{\circ}$ to $57^{\circ} \mathrm{F}$ and rainfall is scanty with 8 to 12 inches annually concentrated in winter and spring; average annual evapotranspiration is about 31 inches per year. This is an extensive, almost continuous, and rather uniform area of shrublands. It constitutes the most arid rangeland of the country. ${ }^{2}$ Monte vegetation is a steppe scrub dominated by microphyllous, xerophytic shrubs from 39 to 118 inches high $^{2}$ (Figs. 2 and 3). The most characteristic plant community dominating large areas of the Monte is composed of Larrea divaricata, Larrea cuneifolia and Larrea nitida; Larrea is the most abundant genus. The herbaceous understory is represented by Pappophorum subbulbosum, Pappophorum mucronulatum, Bouteloua aristoides, Bouteloua barbata, Trichloris crinita, Eragrostis argentina, Stipa clarazii, Stipa tenuis, Poa ligularis, and others. ${ }^{3}$ The soil type is a typical haplocalcid, with an A horizon that is $20 \mathrm{~cm}$

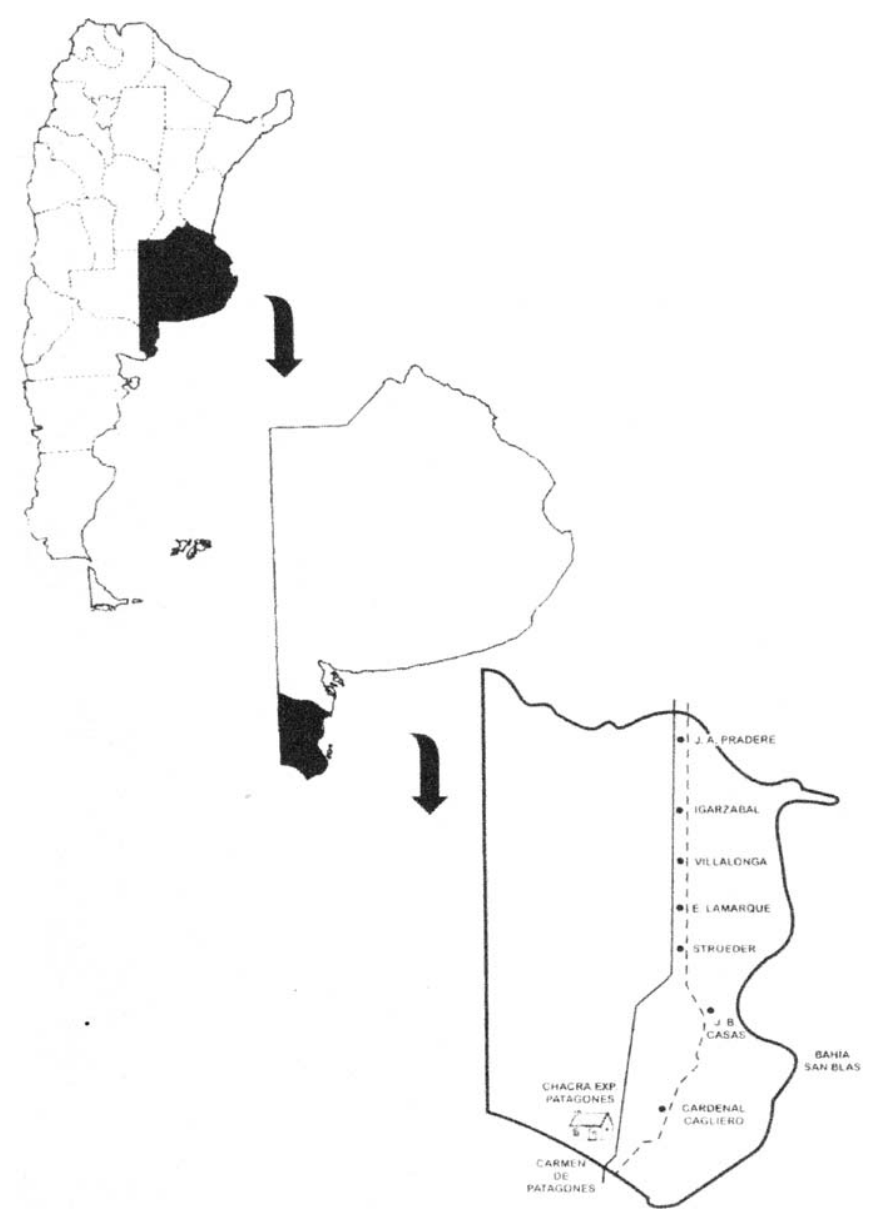

Figure 1. Location of the Chacra Experimental de Patagones in Buenos Aires, Argentina. 
Table 1. Available and assigned forage, stay per paddock, and productive indexes during 1988-1998

\begin{tabular}{|c|c|c|c|c|c|c|c|c|c|c|c|c|}
\hline Year & 1988 & 1989 & 1990 & 1991 & 1992 & 1993 & 1994 & 1995 & 1996 & 1997 & 1998 & Mean \\
\hline $\begin{array}{l}\text { Precipitation } \\
\text { (inches) }\end{array}$ & 14.6 & 10.2 & 16.1 & 12.3 & 24.8 & 13.2 & 12.1 & 10.9 & 13.5 & 27.5 & 11.6 & 15.1 \\
\hline $\begin{array}{l}\text { Total forage } \\
\text { production } \\
\text { (pound/acre) }\end{array}$ & 1514.3 & 974.1 & 785.7 & 626.8 & 672.3 & 808.1 & 261.6 & 228.6 & 233.0 & 670.6 & 939.3 & 701.0 \\
\hline $\begin{array}{l}\text { Assigned } \\
\text { forage } \\
\text { (pound/acre) }\end{array}$ & 896.5 & 605.4 & 450.0 & 383.9 & 390.2 & 486.6 & 175.0 & 168.7 & 169.6 & 446.4 & 674.1 & 440.6 \\
\hline $\begin{array}{l}\text { Observed } \\
\text { stay/paddock } \\
\text { (days) }\end{array}$ & 86 & 52 & 46 & 34 & 52 & 52 & 28 & 19 & 23 & 50 & 72 & 47 \\
\hline $\begin{array}{l}\text { Pregnancy } \\
(\%)\end{array}$ & 94 & 97 & 100 & 86 & 96 & 96 & 89 & 89 & 70 & 92 & 86 & 90 \\
\hline Weaning (\%) & 84 & 90 & 100 & 83 & 93 & 90 & 84 & 84 & 70 & 86 & 89 & 87 \\
\hline $\begin{array}{l}\text { Weight at } \\
\text { weaning } \\
\text { (pound) }\end{array}$ & 394.6 & 410.1 & 451.9 & 434.3 & 454.1 & 432.1 & 372.6 & 363.8 & 330.7 & 346.1 & 319.7 & 391.8 \\
\hline $\begin{array}{l}\text { Beef } \\
\text { production } \\
\text { (pound/acre) }\end{array}$ & 17.0 & 18.7 & 23.2 & 18.7 & 22.3 & 19.6 & 16.1 & 16.1 & 13.4 & 15.2 & 14.3 & 17.7 \\
\hline
\end{tabular}

deep. ${ }^{4}$ This deep soil has a loamy sand texture, with $1.69 \%$ organic carbon, 28.7 parts per million available phosphorus, $0.123 \%$ total nitrogen, and an average $\mathrm{pH}$ of 7 .

There are a few federal rangelands in Argentina. Most rangelands are private properties. The usual livestock producers, private owners, do not know much about how to manage their rangelands properly. Usual beef production on rangelands surrounding the study site is about 8 pounds per acre. ${ }^{5}$ This is considering an average stocking rate of 29.6 acres per animal unit, a weaning percentage of about $60 \%$, and an average weight of 375 pounds of a 7-8-month-old weaned calf. In Argentina, an animal unit is defined as the annual average dry forage requirement of an 882-pound cow that goes through gestation and subsequent nursing of a calf, until the 353-pound, 6-month-old calf is weaned, including the forage consumed by the calf. These values only represent estimates because the breeding season is year-round. ${ }^{6}$ Beef production may be even lower if the calf-cow relationship obtained through agropecuarian census and vaccination programs from Services for Fighting Animal Health Problems is considered. Most rangelands are currently overgrazed, sanitary programs are nonexistent, and infrastructure is deficient.

\section{Procedures}

What follows is a description of changes in several management aspects, which ultimately proved to improve beef production in the experimental unit (Tables 1 and 2) when compared with the usual production system.

\section{Experimental Unit for Beef Production}

This unit was implemented in the Chacra Experimental de Patagones (Figs. 4 and 5) with the objective of obtaining an increased and sustained annual beef production per acre. Local information was then gathered, ${ }^{7,8}$ as were basic management guidelines. ${ }^{1,5,9}$ 


\begin{tabular}{|c|c|c|}
\hline & Average usual production & Production Experimental Unit \\
\hline Stocking rate (acres/animal unit) & 29.6 & 19.3 \\
\hline Bull/cow relationship (\%) & 5 & 3.5 \\
\hline Breeding season & year-round & Nov.-Jan. \\
\hline Pregnancy (\%) & $?$ & 90 \\
\hline Cattle parturition (\%) & - & 92 \\
\hline Weaning \%) & $60^{*}$ & 87 \\
\hline Months to weaning & $7-8$ & 6 \\
\hline Weaning weight (pounds) & 375 & 392 \\
\hline Beef production (pounds/acre/year) & $7.6^{*}$ & 20.0 \\
\hline
\end{tabular}

\section{* Estimated data}

\section{Estimate of Forage Availability}

Annual production of herbaceous vegetation was determined in areas of 49-98 acres. Vegetation included in permanent plots $(n=30 ; 20 \times 20$ inches) was clipped to 1.6 inches stubble height during 11 consecutive years every time cows entered each paddock. It was then separated by species, oven-dried to $158^{\circ} \mathrm{F}$, and weighed. Species were grouped according to palatability: palatable, intermediate (low palatability), and unpalatable. More than $50 \%$ of the total plant biomass was composed by palatable perennial grasses such as S. tenuis, Stipa longiglumis and Poa ligularis, and 27\% corresponded to intermediate perennial grasses (ie, Piptochaetium napostaense, Stipa speciosa, and Aristida spp.).

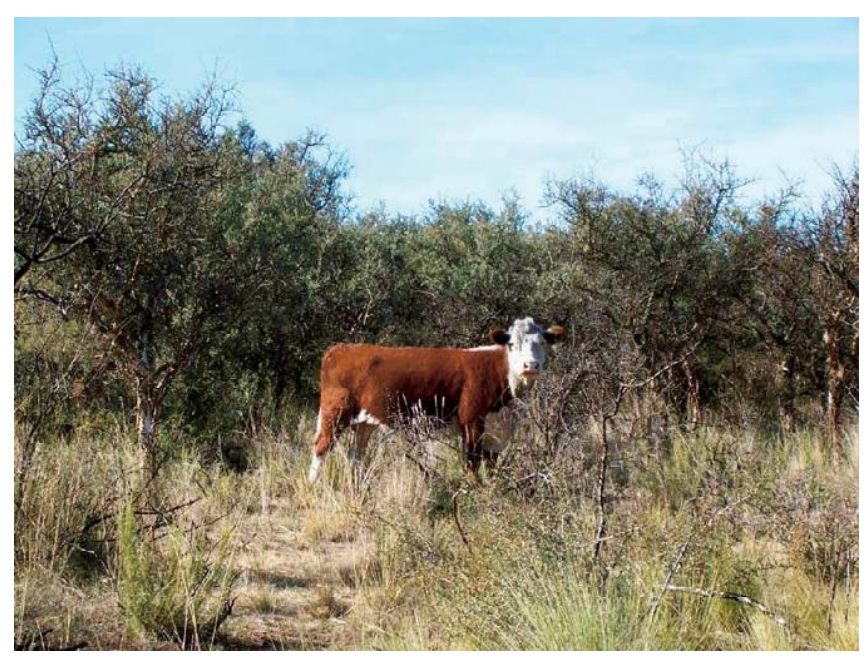

Figure 2. Cattle within the shrubland with herbaceous stratum in the Chacra Experimental de Patagones.

\section{Determination of Stocking Rate}

The following factors were considered to determine stocking rate: forage availability, forage sustained conservation, and cattle-raising requirements for each of its productive cycles. Forage availability was calculated to reach a good rangeland condition. With this purpose, the tendency and cover coefficient (TCC) was modified to determine biomass production. Such a coefficient considers $100 \%$ of palatable perennial grass cover, $50 \%$ of intermediate perennial grass cover, and $25 \%$ cover of annual species to determine rangeland condition. ${ }^{9,10}$ A utilization coefficient of $70 \%$ was used. Stocking rate was adjusted to 19.3 acres per animal unit on the basis of an average annual forage production of 828 pounds dry matter per acre (during the period of 1984-1988), and an

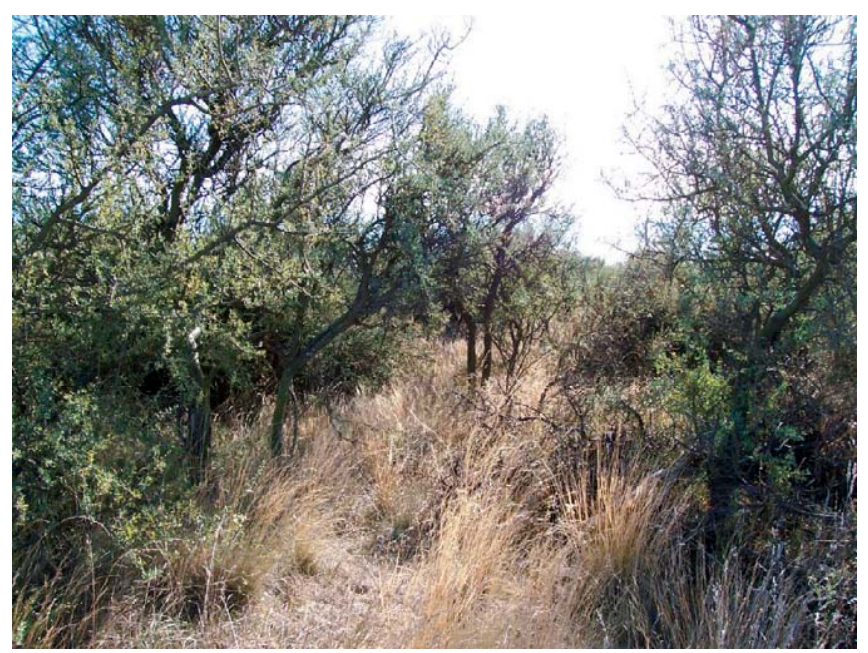

Figure 3. Shrubland with herbaceous stratum in the Chacra Experimental de Patagones. 


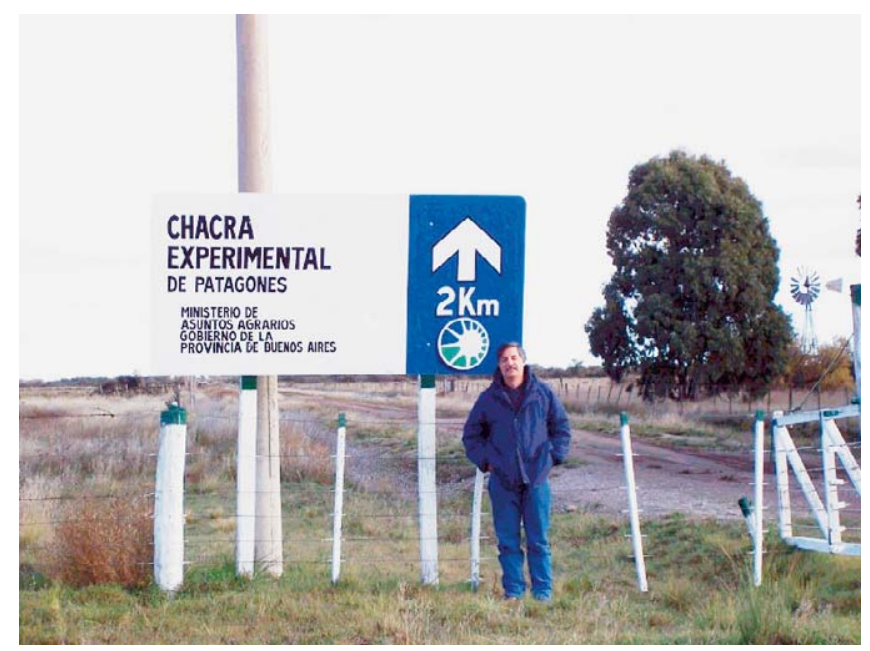

Figure 4. Entrance to the Chacra Experimental de Patagones. Its director, Agronomy Engineer Hugo D. Giorgetti, appears in the picture.

estimate of forage availability of 421 pounds dry matter per acre. Cow-calf requirements were calculated following Cocimano et al, ${ }^{11}$ making adjustments to a monthly average value and considering the following characteristics: parturition during 3 months; weight increases in male and female calves of 1.5 pounds per day until weaning; weaning at the end of summer, and weight maintenance of nonpregnant female cattle.

\section{Infrastructure, Diagram, and Management of the Unit}

A surface area of 535 acres with Monte vegetation (Figs. 2 and 3), was divided with electric wire (Fig. 6) into 8 paddocks of 67 acres each. Initially, 29 Polled Hereford cows were incorporated and after 3 years, 14 of them were replaced by Aberdeen Angus cows. The breeding season was during November, December, and January (midspring to early summer) and cattle were checked for pregnancy by rectal palpation in April (early fall). Bulls composed 3.5\% of the herd; they were removed from the system at the end of the breeding season. Calves were weaned at the end of summer and early in the fall. The percentages of pregnancy, parturition, and weaning, and weights of male and female calves at weaning were determined. Before the animals entered the paddocks, vegetation contained in 10 samples of 387.5 square inches each was clipped to 1.6 inches to estimate forage availability. In agreement with the utilization coefficient, animals grazed the 8 paddocks in a rotative way, with a variable frequency according with the forage grown each year.

Caution should be taken in extrapolating region-wide the new guidelines proposed for improving cattle raising in rangelands of central, semiarid Argentina. This is because the study was replicated in time but not in space. However, and as reported by Hulbert, ${ }^{12}$ when the cost of replication is too high, pseudoreplicated studies can be the only or best option.

\section{Findings}

Stocking rates and paddock surface areas do not change in this production system. What changes is the cattle stay in the paddocks (Table 1). Any variation in stocking rate was the result of variation in the surface area grazed during the rotation system: some paddocks might be grazed more than once depending on year's characteristics (ie, either more or less annual precipitation). The average instantaneous stocking rate used was high (0.38 animal unit per acre), which reduced plant selectivity by animals to a minimum. This increased the utilization efficiency of plants, which can be observed if plant availability is related to stocking rate and stay in the paddocks. For a theoretical daily consumption of 20.5 pounds per animal unit, ${ }^{11} 27.1$ pounds of forage were anticipated (TCC). This would give a utilization efficiency of $75 \%$. In practice, the observed consumption was 22.9 pounds per animal unit. This indicates that utilization efficiency of available forage increased to $85 \%$. Observation of the main productive variables (Table 1 ) shows the stability of beef production achieved throughout years. This was achieved in an environment of highly variable seasonal and annual precipitation regimes, and it shows the advantages of the proposed production system.

Improvements in the productive variables in the Production Experimental Unit allow increases of beef production per acre greater than $160 \%$, in comparison to values found in any usual production system (Table 2). Pound increases in beef production during 4 years are enough to pay off the investments required to carry out the Production Experimental Unit. Improving the production system with the guidelines reported in this manuscript will certainly increase household incomes.

\section{Conclusions}

Management practices such as establishing a breeding season, detecting pregnancy, and practicing rotative grazing are simple and known. The practice of increasing the num-

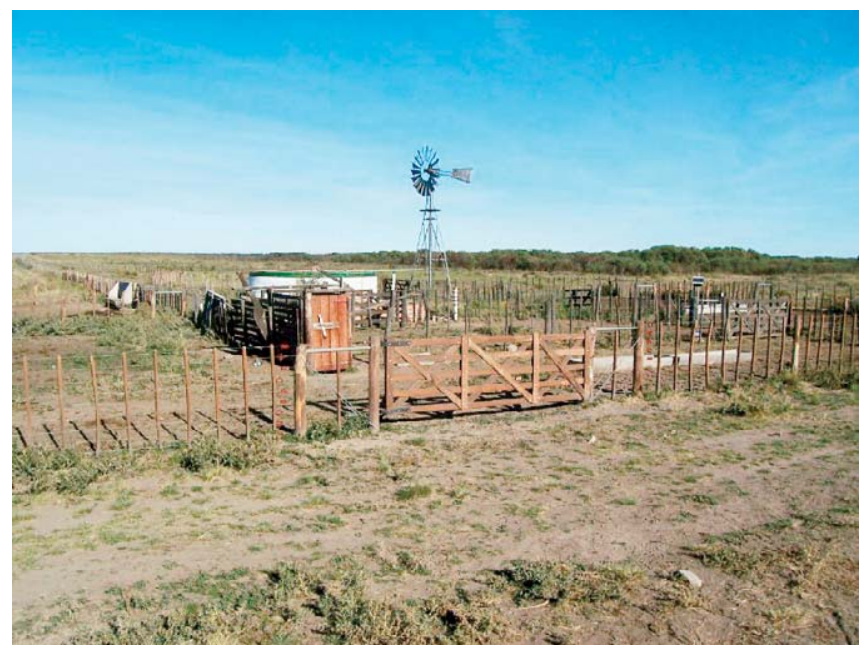

Figure 5. Facilities in the Chacra Experimental de Patagones. 


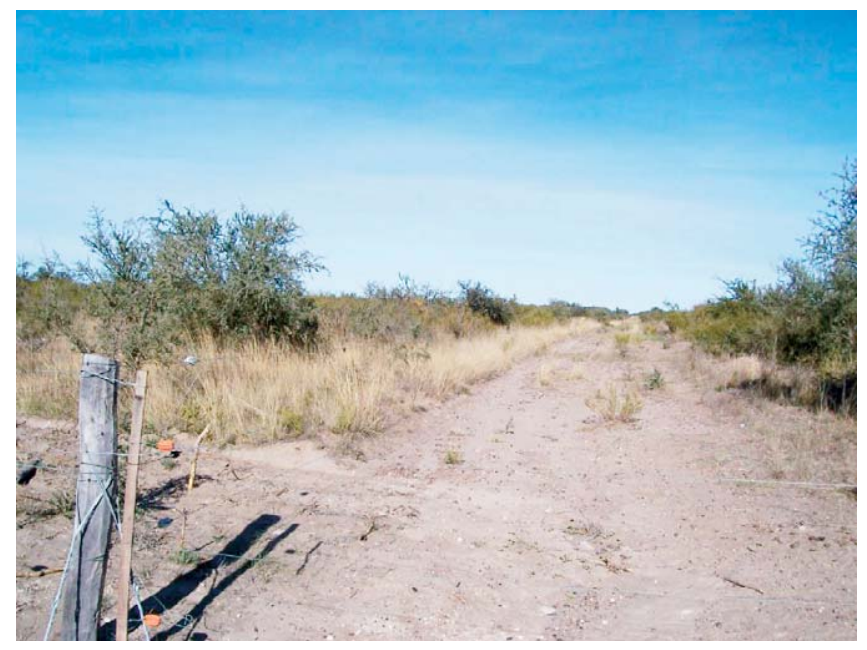

Figure 6. Paddocks divided with electric wire in the Chacra Experimental de Patagones. Notice the electric wire to the left and behind the iron bar close to the wooden post.

ber of paddocks in the same surface area through use of electric wire is not difficult and it reduces costs. Fencing paddocks using electric wire is a simple task that is within the ability of the average livestock owner. Even ranchers with little theoretical knowledge of range management can use high instantaneous stocking rates, which shorten the stay of grazing animals in each paddock so that regrowth consumption of preferred forage can be largely avoided. It is then possible to develop a production system in the region similar to that employed in the Production Experimental Unit. This would allow sustainable increases of beef production per acre and year in the semiarid rangelands of central Argentina.

Authors are Rangeland Scientist, Chacra Experimental de Patagones, Ministerio de Asuntos Agrarios, cc 118, 8504 Carmen de Patagones, Olivera 67, Argentina (Giorgetti); Professor, Departamento de Agronomía-Centro de Recursos Naturales Renovables de la Zona Semiárida (CERZOS), Universidad Nacional del Sur (UNSur) and Research Scientist of the Consejo Nacional de Investigaciones Cientificas y Técnicas de la República Argentina, Altos del Palibue, 8000 Babia Blanca, San Andrés 800, Argentina, cebusso@criba.edu.ar (Busso); Rangeland Scientists, Chacra Experimental de Patagones, Ministerio de Asuntos Agrarios, cc 118, 8504 Carmen de Patagones, Olivera 67, Argentina (Montenegro and Rodríguez); and Rangeland Scientist, Estación Experimental Agropecuaria (E.E.A.) Valle Inferior, Convenio Instituto Nacional de
Tecnología Agropecuaria (INTA)-Provincia de Río Negro, Ruta Nacional Nro. 3, km 971, Argentina (Kugler).

\section{References}

1. CABrera, A. L. 1976. Regiones fitogeográficas Argentinas. In: E. F. Ferreira Sobral [ed.]. Enciclopedia Argentina de Agricultura y Jardinería. Buenos Aires, Argentina: ACME. p 1-85.

2. Fernandez, O. A., And C. A. Busso. 1999. Arid and semiarid rangelands of Argentina. In: O. Arnalds, and S. Archer [eds.]. Case studies of rangeland desertification. Proceedings from an international workshop in Iceland. Reykjavik, Iceland: Agricultural Research Institute.

3. Giorgetti, H., O. A. Montenegro, G. Rodríguez, C. A. Busso, T. Montani, M. A. Burgos, A. C. Flemmer, M. B. TORIBIO, AND S. S. HorviTZ. 1997. The comparative influence of past management and rainfall on range herbaceous standing crop in east-central Argentina: 14 years of observations. Journal of Arid Environments 36:623-637.

4. Saint Pierre, C., C. A. Busso, O. A. Montenegro, G. D. Rodríguez, H. D. Giorgetti, T. Montani, and O. Bravo. 2004. Direct assessment of competitive ability and defoliation tolerance in perennial grasses. Canadian Journal of Plant Science 84:195-204.

5. Menvielle, E. E., C. L. Bertucci, And S. Ubici. 1986. Technical report. Bahía Blanca: Department of Agronomy, National University of the South. p 3.1-3.20.

6. Sassenberg, J. W., And A. Perlo. 1980. Technical report. Patagones: INTA. 43 p.

7. Giorgetti, H. 1989. Technical report Chacra Experimental de Patagones. Buenos Aires, Argentina: Ministerio Asuntos Agrarios y Pesca de la Provincia de Buenos Aires. 85 p.

8. Giorgetti, H., O. Montenegro, G. Rodriguez, C. Busso, T. Montani, M. Burgos, A. Flemmer, M. Toribio, and S. HoRVITZ. 1995. Biomasa de especies herbáceas y su correlación con la precipitación en la Provincia Fitogeográfica del Monte. XVII Reunión Argentina de Ecología; 24-28 April 1995; Mar del Plata, Argentina. Mar del Plata: Reunión Argentina de Ecología. p 166.

9. Anderson, D. L. 1980a. Ecología y manejo de pastizales naturales. San Luis: Instituto Nacional de Tecnología Agropecuaria. II Curso de Manejo de Pastizales. 30 p.

10. Anderson, D. L. 1980b. Fenología, utilización y preferencia animal. Sistemas de pastoreo. San Luis: Instituto Nacional de Tecnología Agropecuaria. II Curso de Manejo de Pastizales. 42 p.

11. Cocimano, M., A. Lange, And E. Menvielle. 1975. Estudios sobre equivalencias ganaderas. Producción Animal 4:161-190.

12. Hurlbert, S. H. 1984. Pseudoreplication and the design of ecological field experiments. Ecological Monographs 54:187-211. 